\title{
分光収束電子回折法による精密結晶構造解析法の開発
}

\author{
東北大学多元物質科学研究所 津田健治
}

\section{Kenji TSUDA: Development of an Accurate Crystal Structure Analysis Method Using Energy-Filtering Convergent-Beam Electron Diffraction}

An accurate crystal structure analysis method has been developed using energy-filtering convergent-beam electron diffraction. Characteristic features of the method, the analysis procedure, some applications are described, together with future prospects.

\section{1. はじめに}

収束電子回折 (Convergent-beam electron diffraction : CBED) 法は，透過型電子顕微鏡 (Transmission electron microscope：TEM）を用いてナノメーターサイズに収束 した電子線を試料に照射して電子回折図形を得る方法で す. 通常の電子回折図形と CBED 図形の比較を $\mathrm{SrTiO}_{3}$ を 例として図 1 に示します。通常の電子回折では平行な電 子線を照射してスポット状の回折波が並ぶ回折図形を得 るのに対して, CBED では電子線の収束角に対応して各回 折波がディスク状に拡がり，ディスク中には複雑な強度 分布が見られます.これは電子回折の強い多重散乱（動力 学回折) 効果によるもので, この効果を通して CBED 図形 には結晶の対称性が直接反映されています。実際, CBED 法は最も強力な結晶点群 ·空間群決定法として用いられ ています1)

図 1 は CBED 図形の中心部分，低散乱角のゼロ次ラウ 工帯 (zeroth-order Laue zone：ZOLZ) 反射ですが，周辺 の高散乱角領域にはリング状に高次ラウエ帯 (Higherorder Laue zone : HOLZ) 反射が観察されます. ZOLZ 反

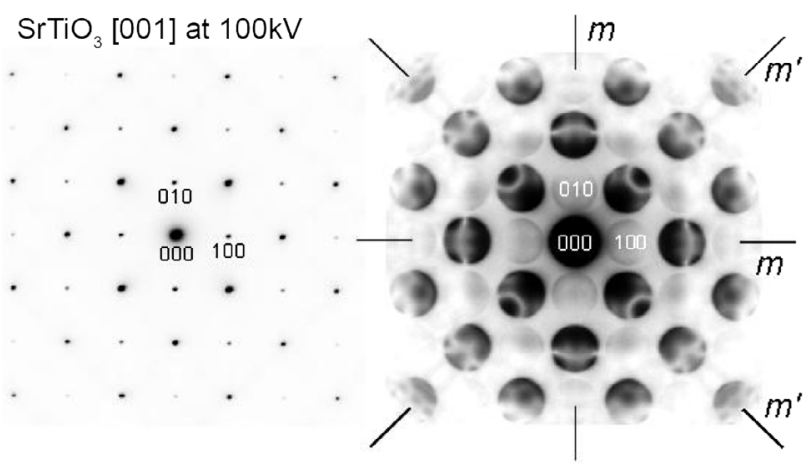

図 $1 \mathrm{SrTiO}_{3}[001]$ 入射の制限視野電子回折図形 (左) と 収束電子回折図形 (右). (Selected-area electron diffraction pattern and convergentbeam electron diffraction (CBED) pattern of $\mathrm{SrTiO}_{3}[001]$.)
射と HOLZ 反射の両方を含む高角までの CBED 図形を 図 2 に示します。回折角の大きいHOLZ反射強度は原 子位置や原子変位パラメーター (Atomic displacement parameter：ADP）に敏感であり, 一方回折角の小さい ZOLZ 反射強度は価電子密度分布の変化に敏感です.

CBED 法の大きな特徵は, 電子顕微鏡像を参照しつつ試 料のナノメーターサイズの領域を選択して CBED 図形を 得ることができる点です (図 3). 図 $3 a$ は $\mathrm{BaTiO}_{3}$ の明視 野電子顕微鏡像で, 試料の厚さ変化, 積層欠陷や強誘電ド メインなどが見られます。このような電子顕微鏡像を見な

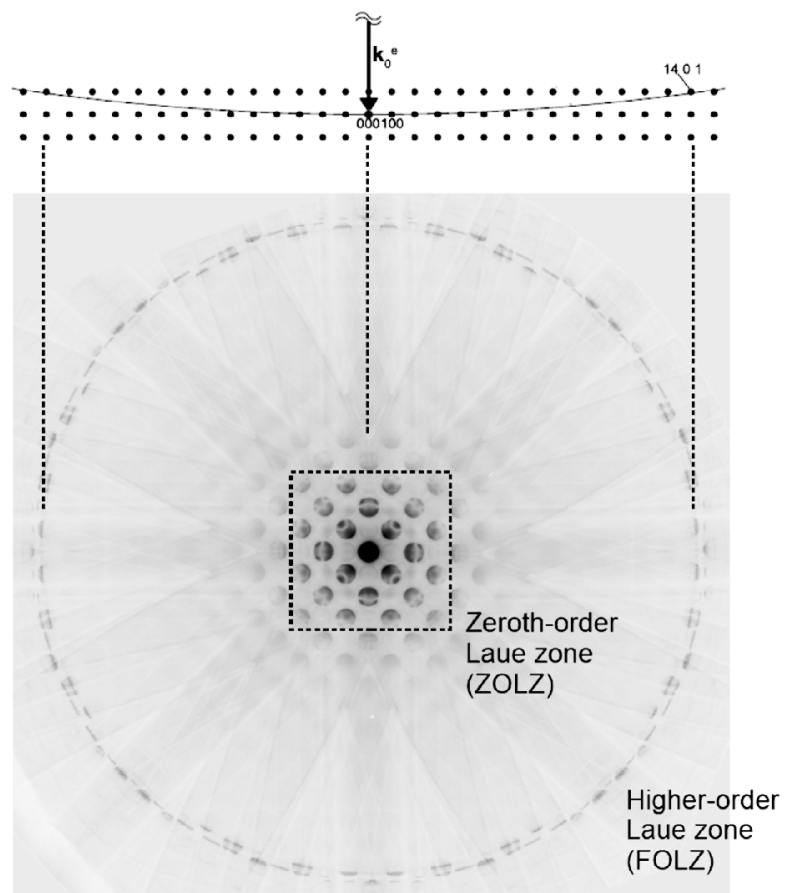

図2 $\mathrm{SrTiO}_{3}[001]$ 入射の高角までの収束電子回折図形 および対応するエワルド球と逆格子点の模式図。 (CBED pattern of $\mathrm{SrTiO}_{3}$ taken at $[001]$ incidence up to a high angle with a schematic diagram of corresponding Ewald sphere and reciprocal lattice points.)

日本結晶学会誌 第 53 巻 第 6 号 (2011) 
(a)

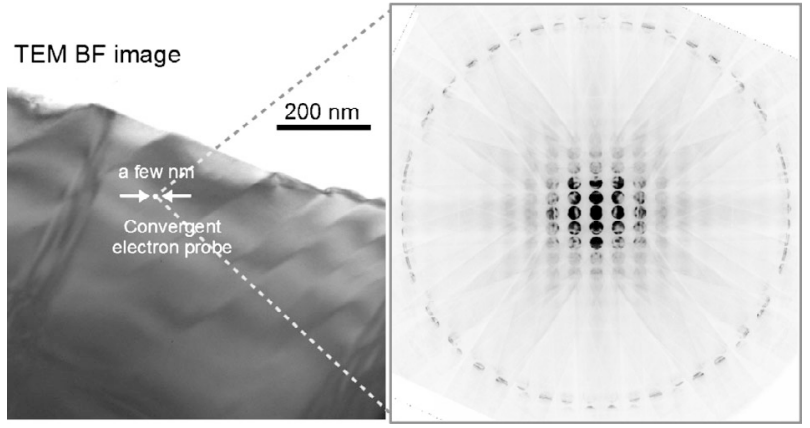

図3 $\mathrm{BaTiO}_{3}$ の明視野電子顕微鏡像 (a) と収束電子回折 困形 (b). (Bright-field transmission microscope image and CBED pattern of $\mathrm{BaTiO}_{3}$.)

がら，任意の場所 (この場合は矢印の場所)を選んで得た CBED図形が図3bです.

CBED 法のほかの特徴として, 見ているものが静電ポテ ンシャル分布である点があります.すなわち電子と核電荷 の散乱への寄与を同時に見ているので, 例えば価電子密度 に変化があると, 電子と核電荷のバランスが変わって特に 低散乱角の回折強度に敏感に変化が現れます。

CBED 法を用いて試料の厚さ・方位一定で完全結晶と みなせる領域から回折強度デー夕を得れば, 動力学回折強 度計算と直接・定量的に比較することが可能となり, ナノ サイズの局所領域から結晶構造パラメーターを精密化し て静電ポテンシャルを求めることができるきわめてユニ 一クな方法となります.われわれは，このような方法の開 発に一貫して取り組んできました.2)-12)

透過型電子顕微鏡では, 近年の電子レンズの収差補正装 置の開発によって電子顕微鏡像の実空間分解能が $0.5 \AA$ 程度まで向上していますが,13) 電子回折では高次反射が 使えるので $0.1 \sim 0.01 \AA$ オーダーの高い分解能が得られ ます。

現在, 世界的にも電子回折を用いた結晶構造解析法の開 発を行っているグループが複数あり，2つの流れがありま す. 1 つぱリセッション電子回折法を用いて動力学回折 効果の影響をできるだけ抑えて三次元の回折強度データ を収集し，運動学近似の範囲で charge flipping 法14),15) や 直接法 15$)$ などにより構造未知物質の初期構造モデルを得 ることを目的とするものです.もう 1 つは CBED図形の強 度を動力学回折理論に基づいて解析するもので, 構造がほ ぼわかっている物質について価電子密度分布などより詳 細な二次構造情報を得ようとするものです. 低次反射の結 晶構造因子を CBED 法で決定し, 高次反射の結晶構造因 子を X 線回折から得て用いるのが普通です. ${ }^{16), 17)}$

われわれの方法は動力学回折理論に基づく構造パラメ ーター精密化という意味では後者に近いのですが, 電子線 データだけを用いて解析を行うという点でほかと一線を 画しています.このことはナノメーター電子プローブの利 日本結晶学会誌 第 53 巻 第 6 号 (2011)
点を最大限に活かすためきわめて重要であると考えてい ます。このためにはCBED図形の低次反射だけでなく高 次反射までの強度測定が必要になり, 電子線のみによる解 析を行っているのは現在世界的にもわれわれのグループ のみです。

本稿では, われわれのグループの, 分光収束電子回折法 による精密結晶構造解析法の開発の経緯と, 解析例をあげ てその特徴について述べます。

\section{2. ハードウエアおよびソフトウエアの開発}

CBED 法を用いた結晶構造解析は, 英国ブリストル大学 のVincent らにより1984年ごろ最初に報告されました18) が, 彼らは準運動学的な近似を用いて解析を行ったため適 用はごく狭い範囲に限られていました. われわれは動力学 回折理論に基づく解析の必要性を主張し, 1988 年ごろか らこの問題に取り組み, 1990 年に世界で初めて動力学回 折理論に基づく原子位置と温度因子の精密化に $\mathrm{SrTiO}_{3}$ を 用いて成功しました.2) この時点では CBEDの実験はエネ ルギーフイルターをもたない通常の透過型電子顕微鏡で 電子顕微鏡用フィルムを用いて行っていました. 非弾性散 乱を抑えるために試料厚さは 2 〜 $300 \AA$ 程度までに抑え て, 強度の読み出しはマイクロデンシトメーターを使用し ました.しばらくして電子顕微鏡用のイメージングプレー トが使えるようになり, 感度・ダイナミックレンジ・精度 が格段に向上しましたが, CBED 図形に重なっている強い 非弾性散乱バックグラウンドを除去するためのエネルギ ーフィルターの必要性が明らかになりました.このため電 子線エネルギー損失分光用のスペクトロメーターを電子 顕微鏡に装着して CBED 図形を得る試みを行い, 非弾性 散乱バックグラウンドの中でも $10 \mathrm{eV}$ 程度以上のプラズ モン損失電子を除去することが定量解析のために最も効

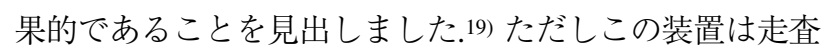
型で検出効率がきわめて悪く結晶構造解析用データの取 得には不十分なものでした。

これらを踏まえて, 検出効率を格段に改善できる二次元 のエネルギーフィルターを搭載した分光収束電子回折用 の透過型電子顕微鏡JEM-2010FEF の開発に取り組みまし た.この開発は田中通義先生を代表とする科研費特別推進 研究 $(1994 １ 997)$ によもので, 日本電子(株)との共同開 発として行われました. それまでに独カールツァイス社か らオメガ型のエネルギーフィルターを搭載した透過型電 子顕微鏡が発売されていましたが, 取り込める角度範囲が 小さく高角の回折波が得られないため, われわれの目的に は使用できないものでした. われわれは, この原因が, 対 物レンズの球面収差のため高角反射がエネルギーフィル ターの入射絞り位置から外れてしまう点にあることを見 出しました。 これを解決できる, 球面収差係数の小さい対 物レンズ $\left(C_{\mathrm{s}}=0.5 \mathrm{~mm}\right)$ とエネルギー分散の大きいオメ 


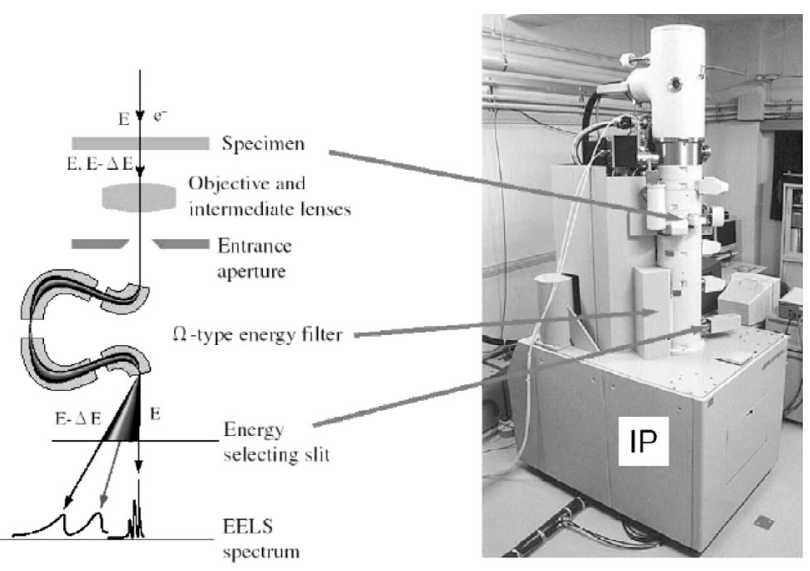

図4 エネルギーフィルター透過型電子顕微鏡 JEM2010FEF. (Energy-filtering transmission electron microscope JEM-2010FEF.)

ガ型エネルギーフィルターを合わせもつ JEM-2010FEF の 開発を行い, 加速電圧 $100 \mathrm{kV}$ 時に回折角 $2 \theta$ が $10^{\circ}$ を超え る高散乱角の HOLZ反射まで一度に取り込むことを世界 で初めて可能としました (図4).20) 当初はオメガ型エネル ギーフィルターに起因する CBED 図形の歪みが問題とな りましたが, フィルターの磁場を調整する歪み補正機構の 導入で解決されました. この電子顕微鏡の開発がブレーク スルーとなり, CBEDによる精密結晶構造解析の道が大き くひらかれました。

図5に, エネルギーフィルターなしで得た通常の CBED 図形とエネルギーフィルターを用いて得た分光 CBED 図 形の比較を [001] 入射 $\mathrm{SrTiO}_{3}$ を例として示します. 通常 の CBED 図形では一様でないバックグラウンド強度がの っており, 矢印で示した弱い 100 反射の強度が判別し難い のに対し，10 eV 程度以上の非弾性散乱強度を取り除い た分光 CBED 図形では 100 反射が明瞭に観察されていま す.このようにエネルギーフィルターを使って非弾性散乱 を取り除くことは定量解析のためにきわめて重要です。

図 2 の $\mathrm{SrTiO}_{3}$ の CBED 図形も JEM-2010FEFを用いて 加速電圧 $100 \mathrm{kV}$ で撮影した分光 CBED 図形であり, $10^{\circ}$ 以上の高角までのCBED図形が得られています。

結晶構造パラメーターの精密化を動力学回折理論に基 ついて行うための解析ソフトウエアの開発も不可欠なも ので, 独自に行う必要がありました. 電子回折の動力学回 折強度計算の最初のコードは, 研究室で使用されていた古 いFORTRANのコードを参考に, FORTRAN77で書きま した.これを当時標準的に使用されていた非線形最小二乗 パッケージSALS と接続し, 最初の動力学回折理論による 構造パラメーター精密化プログラムを作製しました.4)こ のプログラムは, CBED 図形をラインプロファイルとして 取り扱うもので, 二次元データとしての扱いはできません でした。またFORTRAN77 の制約から静的配列しか使用 できなかったため, メモリサイズの制限から実験データご

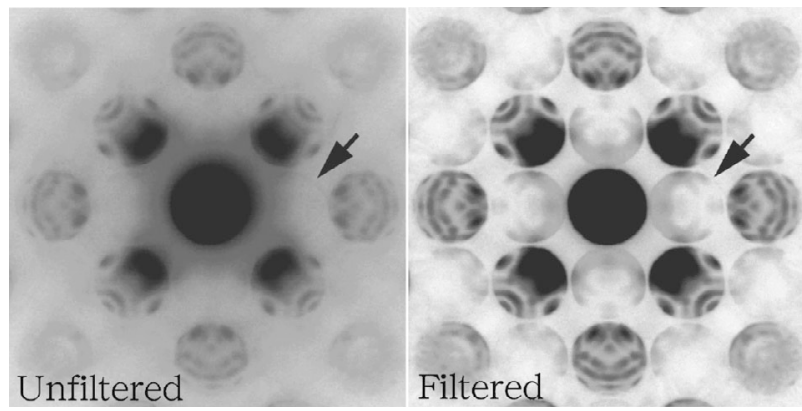

図 $5 \mathrm{SrTiO}_{3}$ の通常の CBED 図形 (左) と分光 CBED 図 形. (Unfiltered and Energy-filtered CBED patterns of $\mathrm{SrTiO}_{3}$.)

とに配列サイズを書き直す必要があり, 結晶構造の記述や 束縛条件なども試料が変わるたびにコード自体を書き直 す不便なものでした．また，当時は計算にべクトル型スー パーコンピューターを使っていたため,コードの読みやす さを犠牲にしたチューンが求められるなど, 種々の制約が ありました。

そこで，動的な配列や構造体が使える C言語で最初か ら全体を書き直すことを 1995 年ごろからスタートして， 現在のコードMBFIT (Many-Beam dynamical simulations and least-squares FITting) を開発しました.5) かなりの時 間をコーディング・デバッグに費やしましたが, 空間群に よる対称性テーブルの利用, 束縛条件のフレキシブルな記 述や新しい実験デー夕構造を取り込むことができ, 現在に 至るまでメンテナンスと機能の追加・改良を継続できて います. 最大の問題は動力学回折強度計算の大きな計算量 です。このため一般化ベーテ近似による行列次数低減や 摂動による Jacobian 計算機能など種々の高速化の工夫を 取り込み，さらにMPI (Message Passing Interface) ライブ ラリを使った並列計算機能を導入することで大幅な高速 化が可能になり,8) 適用範囲がかなり広がりました。試料 の unit cellのサイズにもよりますが，現在使用している 96 core の PC クラスタ計算機を使うと, 数十個の構造パラ メーターを一度に精密化するような計算も可能になって います. MBFIT は, 構造パラメーター精密化の機能以外に も, CBED 図形のシミュレーション, 結晶内で許されるブ ロッホ状態の電子密度分布（図6）や分散面のプロット, 精密化した結晶構造パラメーターから静電ポテンシャル 分布・電子密度分布を求める機能などを含んでいます。 MBFIT のコードは，共同研究者に提供したり，毎年Erice で行われている結晶学国際スクールの, 電子線結晶学の回 で配布するなどしており, 使用者は少しずつ増えているよ うです. MBFIT は ANSI-Cのみで書かれたキャラクター ベースのプログラムですが，米 Northwestern大学の Laurence Marks 教授の電子回折用構造解析パッケージ $\mathrm{EDM}^{21)}$ にも MBFIT コードが取り込まれており, X-window 上でグラフィカルな使用が可能になっています．

日本結晶学会誌 第 53 巻 第 6 号 (2011) 
このほかに,イメージングプレート上に記録したデジタ ル画像からレンズ収差による歪みを補正し, 熱散漫散乱に よるバックグラウンド強度を除去して各反射の二次元強 度分布を取り出すなど, 実験データの前処理用のさまざま な周辺プログラムの開発が必要でした.5)

エネルギーフィルター透過型電子顕微鏡 JEM-2010FEF の開発と, 動力学回折理論に基づく沉用解析プログラム MBFIT の開発により, 分光収束電子回折法による精密構 造解析法を初めて実現することができました. われわれが 構築した解析法の手順をまとめると, 図7のようになりま す.まずエネルギーフイルター透過型電子顕微鏡 JEM2010FEF を用いて, 分光 CBED 図形を撮影します。この 図形から電子レンズによる歪みの補正とエネルギーフィ

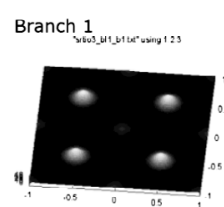

Branch 4 ytos bl bater usran 123

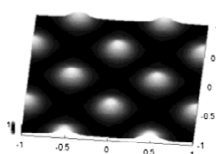

Branch 7

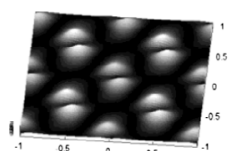

Branch 10.

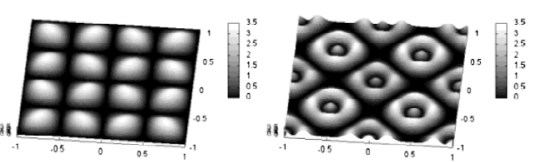

図 $6 \mathrm{SrTiO}_{3}[100]$ 入射での各ブロッホ状態の電子密度 分布. (Electron density distributions of Bloch states of $\mathrm{SrTiO}_{3}$ at $[100]$ incidence.)

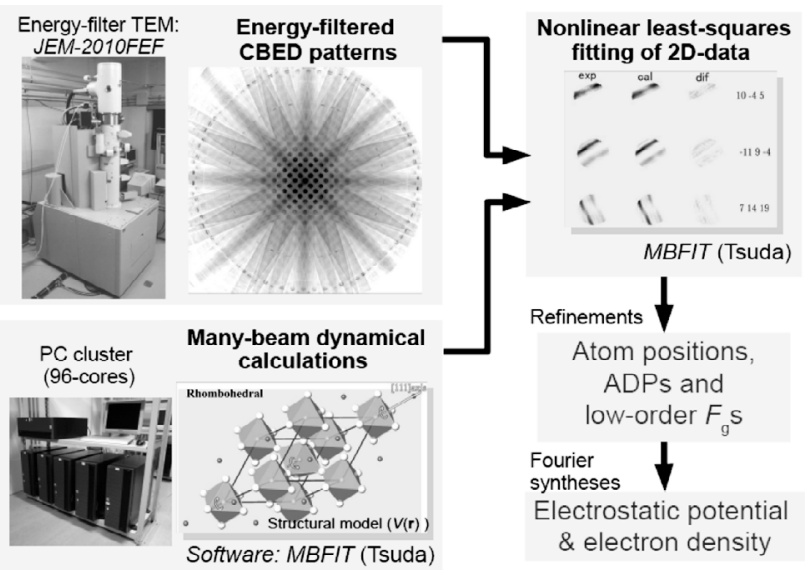

図 7 分光収束電子回折法による精密構造解析の手順.

(Procedure of accurate structure analysis method using CBED.)

日本結晶学会誌 第 53 巻 第 6 号 (2011)
ルターで除去できない熱散漫散乱によるバックグラウン ド強度を解析的に除去し, 各反射ディスクの二次元強度 分布を取り出します.一方, 精密化する結晶構造パラメー ター (原子位置・原子変位パラメーター・占有率・低次結 晶構造因子) を含む結晶構造モデルを作製して動力学回折 強度計算を行います。これら実験と計算の二次元強度分布 を非線形最小二乗法に基ついて定量比較し, 結晶構造パラ メーターを精密化します。さらに, 精密化された結晶構造 パラメーターからフーリエ合成によって静電ポテンシャ ル分布，さらにはPoisson 方程式を用いて静電ポテンシャ ル分布から電子密度分布を得ることができます。

\section{3. 解析例}

われわれの開発した分光収束電子回折法による精密結 晶構造解析法をこれまで種々の結晶に適用してきまし た.5)-12)ここではいくつかの適用例について述べます.

まず $\mathrm{Si}$ の静電ポテンシャル分布解析 10) を取り上げま す. 加速電圧 $100 \mathrm{kV}$, 室温で 11 の異なる入射の分光 CBED 図形を得て, 各回折ディスクの二次元強度分布を取り出 し, MBFITにより動力学回折強度計算とフィッティング を行って, 原子変位パラメーター $(\mathrm{ADP})$ と $\mathrm{g}<0.9 \AA^{-1}$ の 7 種の低次結晶構造因子を精密化しました. フィッティン グ後の各回折ディスクの強度分布の実験，計算および残 差を一部の CBED 図形について図 8 に示します. 実験と 計算はよく一致していることがわかります。この精密化し たパラメーターを用いて静電ポテンシャル分布および電 子密度分布を得ました. このとき低次の結晶構造因子は精 密化した值を用い, それ以外の結晶構造因子は独立原子モ デル (IAM) とADPから值を求めました.

(a)

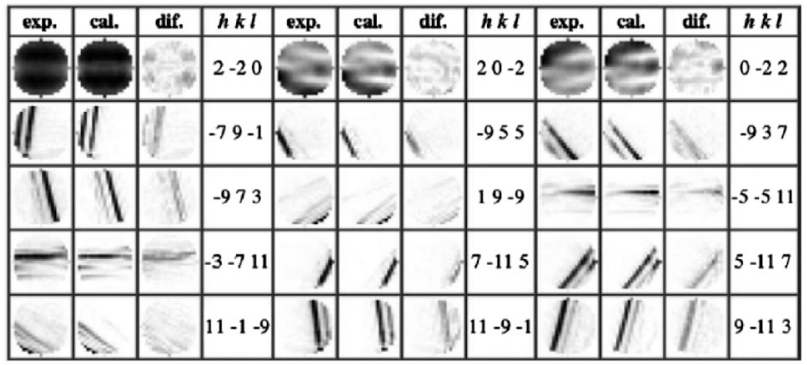

(b)

\begin{tabular}{|c|c|c|c|c|c|c|c|c|c|c|c|}
\hline exp. & cal. & dif. & $h \mathbf{k l}$ & exp. & cal. & dif. & h kl & exp. & cal. & dif. & $h \mathrm{kl}$ \\
\hline & if & & $\left.\begin{array}{llll}-1 & 1 & 1\end{array}\right]$ & (n) & $\overrightarrow{A D}^{2}$ & & $\begin{array}{lll}-1 & 1 & -1\end{array}$ & $\operatorname{lng}_{2}$ & 㩆 & 350 & $1-1-1$ \\
\hline & a. & & $\left.\begin{array}{lll}1 & -1 & 1\end{array}\right]$ & & & & 002 & $\mathrm{~A}_{4}^{2}$ & $\left.7_{i}\right)$ & 67 & -1113 \\
\hline & $i_{t}^{i}$ & 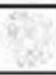 & $1-13$ & $e^{-7}$ & 8 & & -222 & 8 & $x=y$ & & $2-22$ \\
\hline (1) & $(6)$ & 58 & $\begin{array}{lll}0 & 0 & 4\end{array}$ & $f^{2}$ & $y^{i}$ & 8 & -115 & $\hat{k}$ & 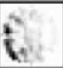 & & $1-15$ \\
\hline
\end{tabular}

図8 Si のフィッティング結果の一部. (Part of final results of fitting of CBED patterns.) (a) [111] 入射 2-20 反射励起，（b） [110] 入射 004 反射励起. 
これら CBED 法で得た静電ポテンシャル分布 $V(\boldsymbol{r})$ を $15 \mathrm{~V}$ の等静電ポテンシャル面として図 9aに示します.

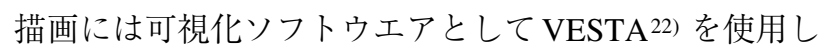
ました.この $V(\boldsymbol{r})$ がCBEDによる精密結晶構造解析で直 接得られるものです。次にこの $V(\boldsymbol{r})$ から $\varepsilon_{0} \nabla^{2} V(\boldsymbol{r})$ を計 算したものが図 $9 b$ です ( $\varepsilon_{0}$ は真空中の誘電率).これはポ アッソン方程式 $\varepsilon_{0} \nabla^{2} V(\boldsymbol{r})=\rho_{\mathrm{e}}(\boldsymbol{r})-\rho_{\mathrm{n}}(\boldsymbol{r})$ により電子密度 $\rho_{\mathrm{e}}(\boldsymbol{r})$ および核電荷密度 $\rho_{\mathrm{n}}(\boldsymbol{r})$ を得たことになります. $0.5 \mathrm{e} / \AA^{3}$ の等密度面を表示しています．隣合う $\mathrm{Si}$ 原子間 ( $\mathrm{e}^{-}$の矢印) に明瞭に結合電子の寄与が見られ，また $\mathrm{Si}$ 原 子の核部分 $\left(\mathrm{n}^{+}\right.$の矢印) にマイナス符号をもつ核電荷密度 が見られます。この核電荷密度部分を ADPから評価して 取り除くと図 $9 c$ の電子密度 $\rho_{\mathrm{e}}(\boldsymbol{r})$ が得られます.

このほかに次のような表示も有用です. $0.5 \mathrm{e} / \mathrm{A}^{3}$ の等電 子密度面の上に静電ポテンシャルの值をグレースケール (a)

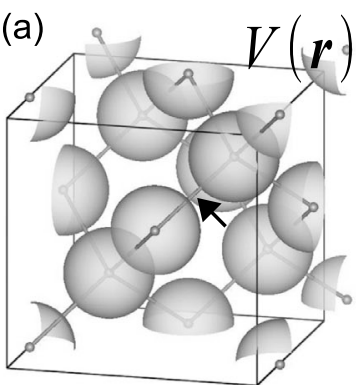

(c)

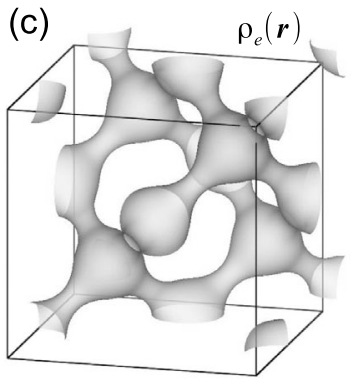

(e)

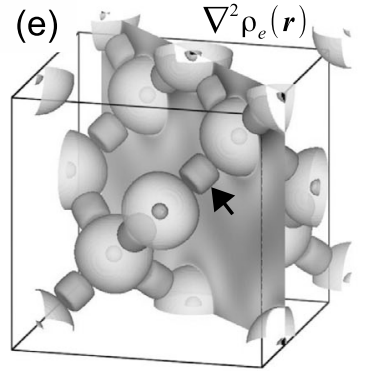

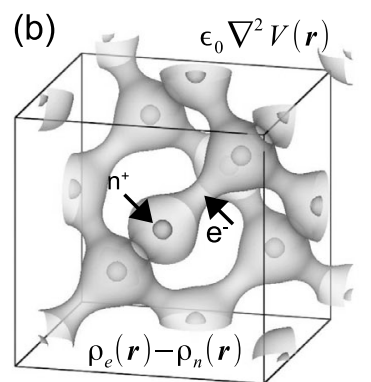

(d)
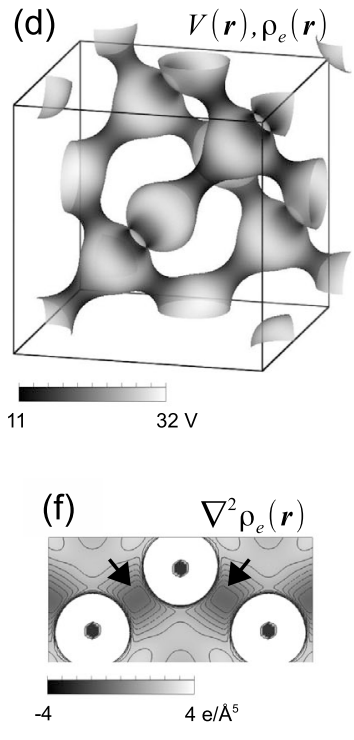

図 9 分光収束電子回折法による $\mathrm{Si}$ の静電ポテンシャル 解析結果. (Results of electrostatic potential analysis of $\mathrm{Si}$ using energy-filtering CBED.) (a) 静電ポテ ンシャル分布の $15 \mathrm{~V}$ 等值面, (b) 静電ポテンシャ ルのラプラシアンの $0.5 \mathrm{e} / \AA^{3}$ 等值面，(c) 電子密 度分布の $0.5 \mathrm{e} / \AA^{3}$ 等密度面，(d) 等電子密度面上 に静電ポテンシャルをグレースケールでプロット したもの，(e) 電子密度のラプラシアンの $1.5 \mathrm{e} / \AA^{5}$ 等值面および (f) その (110) 断面.
でプロットしたものが図 9dで, $\mathrm{Si}$ 原子間の結合電子の位 置で静電ポテンシャルが低下している様子が明瞭にわか ります.この結果はActa Cryst. A 誌の 2009年の Cover photo として採用されています，また，電子密度 $\rho_{\mathrm{e}}(\boldsymbol{r})$ の ラプラシアン $\nabla^{2} \rho_{\mathrm{e}}(\boldsymbol{r})$ を図 $9 \mathrm{e} に 1.5 \mathrm{e} / \AA^{5}$ 等值面として示 します. 最近接原子を含む面でのプロットが図 $9 f$ です.最 近接原子間はラプラシアンが負の領域となっており,これ も共有結合電子の存在を示しています.

次に, スピネル酸化物 $\mathrm{FeCr}_{2} \mathrm{O}_{4}$ の軌道秩序相の解析結 果12)を図 10 に示します. $\mathrm{FeCr}_{2} \mathrm{O}_{4}$ は室温の立方晶相から 約 $135 \mathrm{~K}$ 以下で正方晶へ構造相転移を起こしますが,これ に伴い $\mathrm{FeO}_{4}$ 四面体の $\mathrm{Fe}^{2+}$ イオンの $3 d$ 電子が軌道秩序を 示すと考えられていました. ${ }^{23)} 3$ つの入射方位の CBED 図 形の定量解析を行い, 原子位置 $\cdot A D P \cdot$ 低次結晶構造因 子を精密化して, 静電ポテンシャルおよび電子密度分布を 得ました. $\mathrm{FeO}_{4}$ 四面体の部分を取り出して $4 \mathrm{e} / \AA^{3}$ 等電子 $^{\circ}$ 密度面上に静電ポテンシャル分布をグレースケールでプ ロットしたものを, 室温相掞よび軌道秩序相についてそれ ぞれ図 10a と図10bに示します. 室温相では隣接酸素イ オンに近い位置で, 酸素イオンの電子の影響で静電ポテ ンシャルが低下しています。これに対し軌道秩序相では 等電子密度面の $c$ 軸に沿う方向 (矢印で示した) でも静電 ポテンシャルが低下していることがわかります。これは $\mathrm{Fe} 3 d$ 電子の $3 z^{2}-r^{2}$ 型軌道が $c$ 軸に沿う向きで存在してい ることを示し, 軌道秩序を直接観測したものと言えます.

(a)

(b)
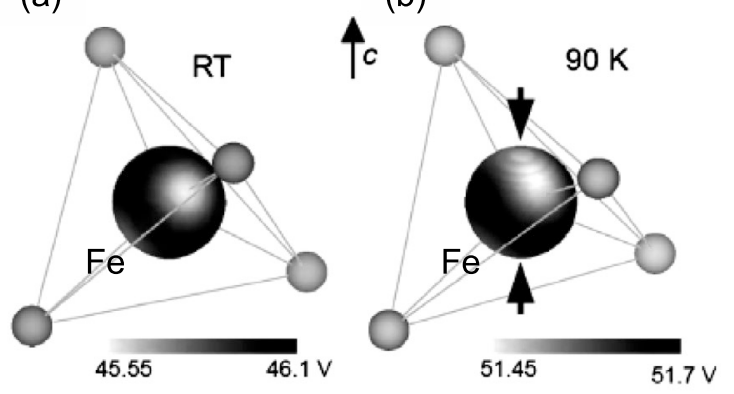

(c)

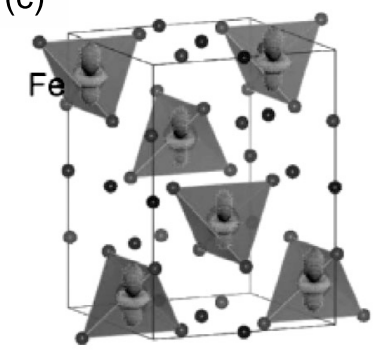

図 $10 \mathrm{FeCr}_{2} \mathrm{O}_{4}$ の $\mathrm{FeO}_{4}$ 四面体の $4 \mathrm{e} / \AA^{3}$ 等電子密度面上 の静電ポテンシャル分布. $\left(4 \mathrm{e} / \AA^{3}\right.$ electron density isosurface of $\mathrm{FeO}_{4}$ tetrahedron of $\mathrm{FeCr}_{2} \mathrm{O}_{4}$ colored with electrostatic potential.) (a) 室温立方晶相, (b) 低温軌道秩序相. (c) Fe $3 d$ 電子の低温軌道秩序 の模式図.

日本結晶学会誌 第 53 巻 第 6 号 (2011) 
(a)

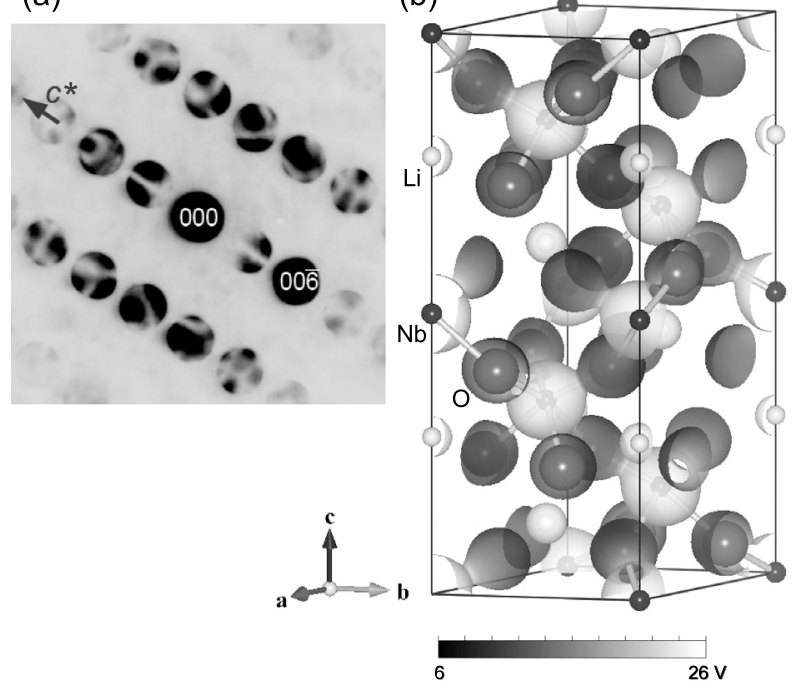

図 11 (a) $\mathrm{LiNbO}_{3}$ の [120] CBED 図形と (b) CBED で得 た静電ポテンシャル分布. $0.75 \mathrm{e} / \AA^{3}$ 等電子密度 面上にプロットしたもの. ( (a) [120] CBED pattern of $\mathrm{LiNbO}_{3}$ and (b) $0.75 \mathrm{e} / \AA^{3}$ electron density isosurface colored with electrostatic potential.)

図 10cにこの軌道秩序を模式的に示しました。このよう な軌道秩序に起因するきわめて小さい異方性は, 電子密度 と静電ポテンシャルのどちらかを見るだけでは検出が難 しく, 等電子密度面を reference としてその上に静電ポテ ンシャルをプロットすることで初めて見出すことができ たものです.

また, 強誘電体 $\mathrm{LiNbO}_{3}$ の解析結果を図 11 に示します. $\mathrm{LiNbO}_{3}$ は $\mathrm{NbO}_{6}$ 八面体を基本とするイルメナイトに類似し た結晶構造をとり, 室温で強誘電性を示します.24) 図 $11 \mathrm{a}$ は加速電圧 $100 \mathrm{kV}$, 室温で得た [210］入射の分光 CBED 図形で, $c^{*}$ 軸に沿う鏡映対称のみが観察され，分極方向 が判別できます.CBED図形を定量解析して，原子位置， ADP および低次結晶構造因子を精密化して, 静電ポテン シャルおよび電子密度分布を得ました. 図 $11 \mathrm{~b}$ は $0.75 \mathrm{e} / \AA^{3}$ の等電子密度面上に静電ポテンシャルをグレースケール でプロットしたものです．電荷移動により，Li および $\mathrm{Nb}$ 周りで静電ポテンシャルが上昇し $\mathrm{O}$ 周りで低下している ことがわかります. $\mathrm{Nb}$ は $\mathrm{NbO}_{6}$ 八面体の中心から $c$ 軸方向 に約 $0.25 \AA$ 変位して強誘電分極の存在を明瞭に示してい ます。

\section{4. おわりに}

われわれの開発してきた分光収束電子回折法による精 密結晶構造解析法について開発経緯を交えて現状を述 ベました.この方法の特徴である,ナノサイズの局所構造 解析, 動力学回折効果による極性判別および静電ポテンシ ヤル分布解析が威力を発揮する系として, 強相関電子系の 電荷・軌道秩序相や, 強誘電体の解析に現在取り組んでい
ます.特に，これまで明らかになっていなかった強誘電体 の局所構造について新しい知見が得られると期待してい ます.

今回述べた方法は周期構造をもつ結晶が対象ですが, 非 周期構造である結晶境界 · 界面の構造解析へのアプロー チも始めています。このためには回折波間の干渉を利用す るコヒーレント CBED 法と呼ばれる方法が有用であると 考えています.25)この方法にはこれまでより干渉性の高 い電子波が必要になりますが, 冷陰極電界放出型電子銃や 球面収差補正装置を備えた最近の透過型電子顕微鏡はま さにこの目的に適しており, 強誘電ドメイン境界の構造解 析など新たな可能性がひらけると考えています.

CBED 法による精密結晶構造解析法の開発は, 大学院修 士課程で田中通義先生からいただいて以来二十云年にわ たって継続して取り組んでいるテーマです. 装置の大型 化・分業化が進み競争の激しい結晶構造解析の分野で, こ のような長期間開発を継続することができ, かつハードウ エア・ソフトウエア開発のほぼすべてに携わってこれた ことは, 大変幸せなことだと強く思います. そのようなき わめて稀有な環境とご指導, 多大な励ましをいただいた東 北大学名誉教授の田中通義先生と, 多大なサポートをいた だいている寺内正己教授に深く感謝いたします。もちろ ん, ハードウエアおよびソフトウエア開発, 構造解析の共 同研究でお世話になりました多数の方々のお力添えなし には.このような開発は不可能でした.この場をお借りし て深く御礼申し上げます。本手法が活躍できる場を求め て, 今後とも手法の改良と応用に取り組んでいきたいと考 えております。

\section{文 献}

1) M. Tanaka: International Tables for Crystallography, 3rd ed., U. Shumueli ed., Vol.B, 307, IUCr, Springer (2008).

2) M. Tanaka and K. Tsuda: Proc. XII Int. Cong. on Electron Microscopy, Seattle, San Francisco Press, 518 (1990).

3）津田健治, 田中通義：日本結晶学会誌 36, 246 (1994).

4) K. Tsuda and M. Tanaka: Acta Cryst. A51, 7 (1995).

5) K. Tsuda and M. Tanaka: Acta Cryst. A55, 939 (1999).

6) K. Tsuda, K. Takagi, Y. Ogata, T. Hashimoto and M. Tanaka: Acta Cryst. A58, 514 (2002).

7) 津田健治：日本結晶学会誌 44, 269 (2002).

8) Y. Ogata, K. Tsuda, Y. Akishige and M. Tanaka: Acta Cryst. A60, 525 (2004).

9) 津田健治：日本結晶学会誌 47, 50 (2005).

10) Y. Ogata, K. Tsuda and M. Tanaka: Acta Cryst. A64, 587 (2008).

11) K. Tsuda, D. Morikawa, Y. Watanabe, S. Ohtani and T. Arima: Phys. Rev. B 81, 180102(R) (2010).

12) 津田健治：日本結晶学会誌 52, 184 (2010).

13) K. Urban: Science 321, 508 (2008).

14) A. Eggeman, T. White and P. Midgley: Acta Cryst. A65, 120 (2009).

15) E. Mugnaioli, T. Gorelik and U. Kolb: Ultramicrosc. 109, 758 (2009). 
16) J. M. Zuo, M. Kim, M. O'Keeffe and J. C. H. Spence: Nature (London) 401, 49 (1999).

17) P. N. H. Nakashima, A. E. Smith, J. Etheridge and B. C. Muddle: Science 331, 1583 (2011).

18) R. Vincent, D. M. Bird and J. W. Steeds: Phil. Mag. A50, 745 (1984) ; R. Vincent, D. M. Bird and J. W. Steeds: Phil. Mag. A50, 765 (1984).

19) M. Tanaka and K. Tsuda: Proc. 26th Meeting of Microbeam Analysis Soc, San Jose, San Francisco Press, 145 (1991).

20) M. Tanaka, K. Tsuda, M. Terauchi, K. Tsuno, T. Kaneyama, T. Honda and M. Ishida: J. Microscopy 194, 219 (1999).

21) EDM: Electron Direct Methods, L. Marks, http://www.numis. northwestern.edu/edm/

22) K. Momma and F. Izumi: J. Appl. Cryst. 44, 1272 (2011).

23) T. Arima, Y. Watanabe, K. Taniguchi, M. Watanabe and Y. Noda: J. Magn. Magn. Mater. 310, 807 (2007).

24) B. T. Matthias and J. P. Remeika: Phys. Rev. 76, 1886 (1949).

25) K. Tsuda and M. Tanaka: J. Electron Microsc. 45, 59 (1996).

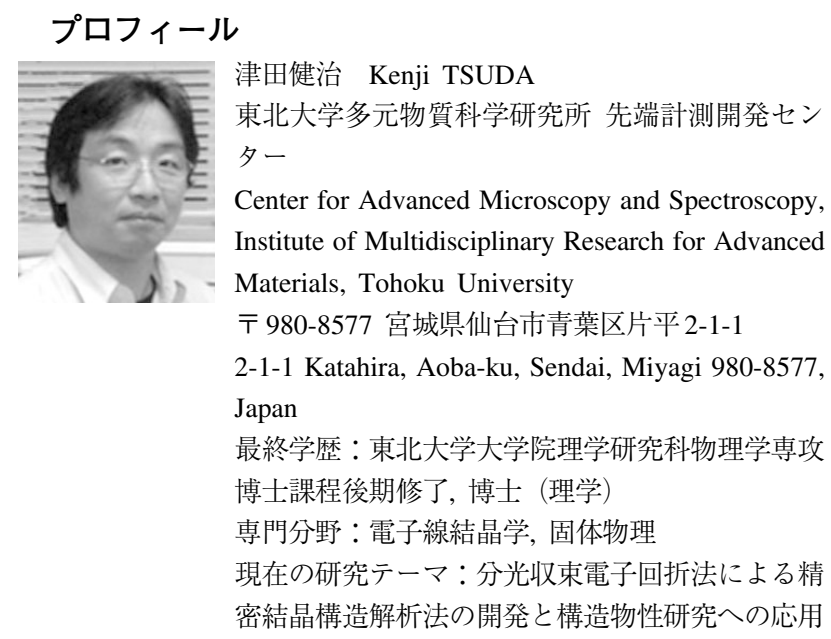

